NBER WORKING PAPER SERIES

\title{
ENERGY TAXES AND AGGREGATE \\ ECONOMIC ACTIVITY
}

Julio J. Rotemberg

Michael Woodford

Working Paper No. 4576

\section{NATIONAL BUREAU OF ECONOMIC RESEARCH 1050 Massachusetts Avenue \\ Cambridge, MA 02138 \\ December, 1993}

We would like to thank Jim Costain for his untiring research assistance, Jim Poterba for his comments and the NSF for research support. This paper is part of NBER's research programs in Economic Fluctuations and Public Economics. Any apinions expressed are those of the authors and not those of the National Bureau of Economic Research. 
NBER Working Paper \#4576

December 1993

\title{
ENERGY TAXES AND AGGREGATE \\ ECONOMIC ACTIVTTY
}

\begin{abstract}
This paper shows that the output losses from energy taxes are significantly larger than usually computed when due account is taken of imperfect competition among energy using fims. Even with perfect competition among these firms, the loss in GNP is of the same order of magnitude as the revenue raised by these taxes. However, in the presence of imperfect competition the output losses are much higher. There are particularly large transitory losses in the immediate aftermath of energy price increases when firms act as implicitly colluding oligopolists. These losses become considerably smaller if energy taxes are phased-in. We also show that taxes that affect only household consumption of energy have much smaller effects. In particular, for the empirically plausible parameter values we consider, such taxes have no effect on employment or output in the non-energy sector.
\end{abstract}

Julio J, Rotemberg

Department of Economics, E52-432

Massachusetts Institute of Technology

50 Memorial Drive

Cambridge, MA 02139

and NBER
Michael Woodford

Department of Economics

University of Chicago

1126 E. 59th Street

Chicago, IL 60637

and NBER 
As part of his address to a joint gession of Congress on Febtuary 17, 1993, President Clinton propoued a brond-based energy tax, a a central part of his plan to reduce the size of the U.S. government budget Weficil. Ihad this "BTU tax" been enacted, crude oil would eventually have been subject to approximately a $21 \%$ Lax, coal to a $25.7 \%$ tax and natural gas to a $16 \%$ tax. Somewhat lower taxes would have applied to hydroelectricily and nuclear power. The political tesistance to this energy tax was, however, intense, and when the dust aettled, all that was enacted was about a $4 \%$ tax on gasoline.

One of the reasons advanced for resislance to the energy tax was concern aboul its impact on production and employment in U.S. industry. Indeed, existing studies of the effect of carbon taxes (Goulder (1992, $1593 \mathrm{a}, 1993 \mathrm{~b})$, Jorgenson and Wilcoxen (1993)) auggest that the reductions in GDP caused by these taxes are conparable to the amount of revenue they raise. To demonetrate that this is more onerous than the losses caused by other taxes, these authors show that GDP still falls substantially even if the revenues from the carbon tax are used to reduce existing labor income taxes. 1 That energy taxes are so deleterious may seem surprising, since energy consumplion is a relatively mall fraction of GDP. But the share of energy costa in total costs doe not aflect the analysis because the amall ahare of spending on energy also reduces proportionally the cevenue raiged by a given ad valorem tax rate. Neither does our analyifa hinge on the fict that, in practice, other inputs are used to produce energy. Thus the cost of energy taxes we diacuse is linrelated to Diamond and Mirrlees' (1971) prool that it is inefficient to tax intermediate inputs; energy is actually a raw material in our model since we neglect extraction costs. Rather the cost of energy taxes pcsulis from the fact that, unlike other caw materials such as labor, energy is relatively elastically aupplied. As a zesult, the quantily of the energy input falls substantialy in response to a tax, instead of the factor price simply being torced down.

Iu this poper, we argue that the contractionary eftects of energy taxes on energy-using industries are even litger than is usually computed, once due account is taken of imperfect competition in those iuctustries. " The presence of imperfect competition implies that the price of output is abowe the marginal cost of prodtction. Thus the social benefit from increasing output by one unit exceds the social cost of

\footnotetext{
I Of course, an appoprialely atruelured trergy tax also has a benefit that other tinds of wxe do not, which in the provision

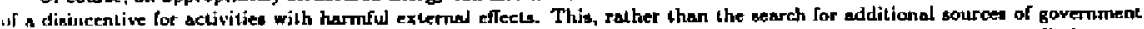

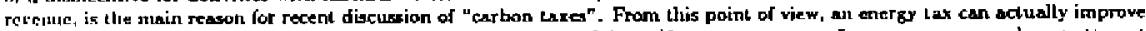

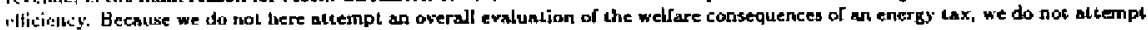
ls quartify' such effects. For an attempt to do 20, see Goulder (1993b)

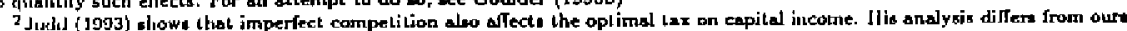
lineane capiial goods are incemediate inputs wherens we treat energy at a raw malerial.
} 
doing so. This wedge implies that a reduction in oulput has more deleterious wellare consequences in the presence of imperfect competition. Thus, the preexisting distortion due to the lack of perfect competition raises the welfare costs of any particulat output teduction, whatever its origin. Welrare costs ate not out main tocus here, lowever. We study instead the degree to which output falls and show that this wo is larger with imperfect competition.

The reason is twofold. First of ail, imperfect competition implies that the marginal product of any factor, including energy, exceeds its price. This means that the reductions in energy and other inputs that result from encrgy taxes reduce GNP by more than one would estimale simply based upon these inputs' measured cost slares.

Secondly, if the tax change increases the degree of market power of firms in their product markets, they increase the exlent to which they mark up their prices relative to their narginal costs, which reaults in a contraction of the equilibrium level of production, just as if a tax on inputs had increased those marginal costs. We show that even a very small increase in market power can have a large effect upon the predieted output decline, because the markup increase is like a tax on all inputs, and not just energy. We also show that a particular moded of endogenous matkup determination (the model of oligopolistic pricing previously used in Rolemberg and Woodford (1991, 1992, 1993)) can imply a temporary increase in market power following an energy tax increase, though the eflect is transilory even in the case of a permanent tax increase. We also show that this eflect is even stronger if one allows for uncertainty about the permanence of the tax cliange.

We also show that allowing for imperfect competition has important consequences for evaluation of the relatiwe merits of alternatively structured energy taxes. In particular, we show that gradual phase-in of an cncegy tax mitigates the contractionary effects in the short run, to an even grealer extent than revenue are ceduced over that same period; and this effect is even more pronounced when imperfect competition is taken into account.

Our method is to numerically solve a calibraled general equilibrium simulation model, under alternative atssumptions about product market structure. Out model decomposes energy into energy purchased directly by houscliolds and energy bought indirectly via the purclase of otlyer produced goods. This allows us to analyze the difference between taxes on all energy use and taxes on directly consumed energy. 
This paper is relaled to Rotemberg and Woodford (1993), where we considered the ability of a similar range of alternative modela to explain the large declines in US. output that followed pre-1980 inctease in the price of oil. We showed that it wrs easiest to explain these contractions of output, as well as the simultanenus declines in real wages, if one viewed firms as not only baving market power but as implicitly collusive. ${ }^{3}$ The numerical calibration of the "varinble markup" model considered here matehes that of the model stown in the previous paper to best fit the observed effects of oil price shocks. This gives us gome reason to suppose that imperfectly competitive effects of the gize assumed in our aimulationa may actually be present in the U.S. economy.

Section 1 sets the stage by describing the U.S. energy maket. Section 2 discusses the behavior of the firms that use this energy to produce final output. In this section, we also give an intuitive explanation for the importance of imperfect competition in determining the output loses caused by energy taxes. Section 3 then describes the rest of aur simulation model. Sections 4 and 5 then present the model's numerical predictions regarding, respectively, the long-run and short-run effects of an unexpected permanent increase in energy (axes. In section 6 we take up the effect of predieted changes in energy taxes. We thus consider both the eflect of phased-in taxes as well as the effects of taxes that are expected to be repealed. Finally, section $\bar{T}$ concludes.

\section{The U.S. Energy Market}

Four types of products account for the vast bulk of energy consumption. These inciude coal, natural gas, petroleuin products and electricily. For our purposes, we wish to obtain an energy aggregate. One common aрpтолcli is to add together the BTU's contained in all fout sources of energy. This would make sense if the products were perfecl substitutes in the sense tliat a BTU from one source is as use[ul as a BTU from inother. Ilowever, in practice, the price per BTU is rather different for different sources of energy. In particular, it is higher for oil than for coal. For that reason, our aggregate is obtained by adding together the expenditure on these four products. This too is striclly appropriate only if lhe products are perfect sulbstitill.es. However, it allows the BTU's from one source to be Iess use[ul than those from another.

\footnotetext{
${ }^{3}$ The sune model of oligopolintic pricing is shown in Rotembers and Woodford ( 1991 ) to be useiul in explaining cyclical

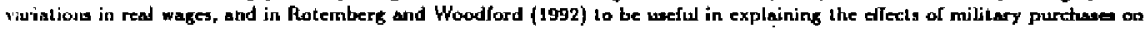
real winges.
} 
The aggregation of these four energy sources is complicated by the fact that coal, gas and petroleum products are used in the generation of electricity (though some electricily is also generated from other sourcey). It would thus be incorrect to simply add together the values of coat, natural gas, petroleum products and electricity sales. What we do instead is to count only the coal, aatural gas and petroleum products that are not sold to electric utilities.

Table 1 presenks data on the sales of these four producis in 1989 . Most of coal is used for electric generation. We valued the $\mathbf{1 0 0}$ million metric tons that are consumed in other sectors at the average CIF price paid by electric utilities, namely $\$ 30.43$ per ton. To value both domestically produced and imported crude oil, we used the average import price of $\$ 16.54$ per barrel. Electric vtilities do not use crude oil diretly. Rather, they buy a combinstion of different petroleum products. Over half of these are made up of residual fuels whose average price was $\$ 18.65$ per barrel. We assigned this price to the entire volume of petroleum producls purchased by electric utilities. Being bigher than the price of crude oil, electric utilities are effectively also purchasing some of the value added of the refining gector. This does not pose any conceptual dificulties since we add the entire value added of the patroleum and coal products sector to our aggregate.

In the case of natural gas, we start with the revenucs of the induglry. 1 We then subtract the gas purcliased by electric utilities using the average price paid by them for natural gas. ${ }^{5}$ Finally, we add the total revenues by electric utilities to our aggregate. We conclude that energy consunption in 1989 was equal to 365.4 Billion dollars, or about 6.6\% of GDP. Of this, imported oil arcounts for $\$ 62.3$ billion, or .17 of the total, and 1.1\% of GDP.

We have less accurale datin for the breakdown of energy use between direct household use and non-energy production. In the case o[ electricily revepue, we know that approximatedy $1 / 3$ comes from residential sales. In the case of the gas sector, we know that residential gales account for $\$ 25.4$ billion in 1990 , or $40 \%$ of the lotal revenues counted above. In Office of Technology Assessment (1990), lolal U.S. energy use in 1985 is reported as 74.9 quads (quadrillion BTU's), of which 28 quads are reported for direct household energy use. This is $37 \%$ of the lotal. Ilowever, government direct use is also reported as 3 quads, so that useg in production (assuming that all energy use other than the two calegories jusl mentioned stould be counted

\footnotetext{
'Frotin the Survey of Current Businest

SFrom the 1950 Annual Energy Survey
} 
as such) are only $59 \%$ of the total. Assuming that 6 of the costs calculated in the previous paragraph are energy inputs inlo non-energy production, we obtain energy cosis with a value of $4.0 \%$ of GDP. Subtracting out the $5.5 \%$ of GDP representing value added by the domestic enefgy indusiry (6.6\% minus $1.1 \%$ from above), value added in the non-energy sector representa $94.5 \%$ of GDP, so that energy costs in that sector are $4.2 \%$ of value added. The energy sector is thus not an extremely large one. It is thus gomewhat surprising that taxes on the output of this sector have such large effects on aggregate activity.

\section{Why Imperfect Competition Matters}

We show below that the effects of energy taxes on aggregate activity are much larger when accounl is taken of inper lect competition among the firms that purchase energy. In this section we provide some intuition for this result by considering a simplified model. Suppose that output is produced with just two inputs, labor $H$ and energy $E$. In particular, each firm has a Cobb-Douglas production function of the form

$$
Y_{i}^{i}=A\left(H_{i}^{i}-H\right)^{1-\alpha}\left(E_{i}^{i}\right)^{\alpha}
$$

where $Y_{1}^{i}$ is the output of firm $i$ in period $t$, while $H_{i}^{i}$ and $E_{t}^{i}$ represent its labor and energy inputs respectively. The parameter $\bar{H}$ repregents a fixed amount of "overhead" labor needed to carcy out any production at all. -The assumption that there are fixed costs ensures that the production funclion exhibits increasing returns to scale in the sense that average costs exceed marginal costs. Our model requires us to assume such increasing returns to acaic. Otherwise, it is impossible to reconcile the gap between price and marginat cost implied by the absence of perfect competition with the apparent absence of pure profits in U.S. industry.

Given the production lunction in 1, the marginal product of energy is $\alpha Y_{1}^{i} / E_{i}^{i}$ or, equivalently, $\alpha A\left[\left(H_{i}^{i}-\right.\right.$ $\left.\bar{W}) / E_{2}^{i}\right]^{1-0}$. Under perfect competition, this marginal product is sel equal to the real price of encrgy, i.e., to the price of energy divided by the price of output. But, under imperfect. competition, the price of output is higluer relative lo marginal coat. In this case one instead oblains.

$$
\alpha A\left(\frac{H_{i}^{i}-\bar{H}}{E_{i}^{i}}\right)^{1-\sigma}=\mu_{t}^{i} p_{E t}
$$

where $\mu_{f}^{\prime}$ is the ratio of firm i's prite to its marginal cost in period $t$, and pet is the real price of energy at $t$. Equation 2 has two implications, both of which make energy taxes unore contractionary in the case of imperfect competilion. First, a high $\mu_{\text {f }}^{i}$ implies a higher marginal product of energy, given any observed 
real energy price. The fact that the marginal product of energy is higher implics that any given reduction in energy inputs lowers oulput by more under imperferl competition.

To see this mote formally, note that I implies that a one percent reduction in $E$ lowers output by $\alpha$ percent. The queation is what value abould be assigned to $\alpha$. Under per[ect competition, 2 implies that it equals the energy share $p_{E 1} E_{i}^{i} / Y_{i}^{i}$, and this is the usual method of assigning a numerical value to this parameter. But with a markup diferent from one, the energy shase instead equals $\alpha / \mu$. Thus a higher markup implies a higher value for $\alpha$, and thus a higher elasticity of output wilh respect to energy, given an obgerved energy share (as calculaled in the previous section).

This atill leaves the question of whether the energy input falls more under perfect or under imperfect competition. A second implication of 2 is that, holding employment fixed, the energy input falls more under imperfect competition. Holding employment fixed is ressonable if one expects labor to be supplied inelastically in the long run. Then 2 implies that a one percent increase in the price of energy will lead to a $1 /(1-\alpha)$ percent reduction in the demand for energy. This fall is larger the larger is one's estimate of $\alpha$, and thus the larger is the departure from perfect competition.

The intuition for this result is the following. Suppose that one observes that, with a given amount of employment, an economy produces 7 units of output with 50 units of energy input. Figure 1 displays two possible Cobb-Douglas production lunctions that could have led to this outcome. In the first $\alpha$ is equal to 0.5, while in the second $\alpha$ is equal to 0.7. They ditet in that the marginal producl. of energy at the observed level of oulput is different. The function with $\alpha$ equal to 0.5 might be inferred, given the observed real price of energy, if one believed that firms are perfectly competilive, while the function with $\alpha$ equal to 0.7 might be inferred under imperfect competition. An important difference between the two functions is that the one with $\alpha$ equal to 0.7 is less bowed towards the origin, leys concave. The smaller concavity of this function is dictated by the fact that hoth eurves go through the origin and through point $A$, while the one with $\alpha=0.7$ is steeper at $A$. The smaller concavity or the $\alpha=0.7$ function implics that a given percentage change in its slope, x.e, in the marginal produch of energy, must lead to a larger change in the cnergy input. ${ }^{6}$ Thus imperfect competition implies a larger change in the energy jnpul from a given purcentage tax on energy,

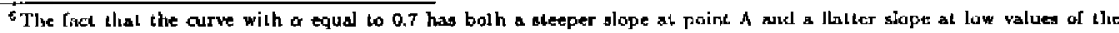
energy input implies thrl the olope of this eurve rises by lew in percentage terms as otie decreases tlie energy inpul from point A to a low pasitive value.
} 
given otserved values for output, the energy input, and the real price of energy at point $A$.

Under imper fect competition, the increase in energy taxes also bas the potential of raising the equilibrium markup $\mu_{i}^{i}$. It Collows inumediately from 2 that an increage in the markup will, with conatnnt employment, lead to a further contraction in energy inputs and thus in oulput. Our simulations below show that in the case of a model of oligopolistic collusion, an increase in the energy Lax does cause an jncreage in the equilibrium markup. In this case, imperfect competition has an even greater effect on our resulta.

\section{A Simulation Model with Imperfectly Competitive Product Markets}

As was noted above, our simulation model is similar in structure to the one used in Rotemberg and Woodford (1993) to analyze the effecls of ail price ahocks. Some modification are required, however, for our present purposes. In particular, our interest in permanent tax changes requires that we take account of the effects of entry and exit in the long run. We also distinguish here between the use of energy in production end direct bousehold use of energy-

The production function in our eimulation model is much more general than the one used in the previous section for illustrative purposes. Like Goulder (1992), we essume that each firm in the private non-energy' secto: produces goods each period with a production function of the form

$$
Y_{i}^{i}=Q\left(V\left(K_{1}^{i}, z_{t} H_{1}^{i}\right), G\left(E_{t}^{i}, M_{i}^{i}\right)\right)
$$

where $K_{t}^{-i}$, and $M_{i}^{i}$ represent, respetively, firm $i^{-3}$ capital and materials inputs at time $t$ while $z_{1}$ indicates an exogenously given labot-augmenting lechnology factor. The aggregator $Q$ for value added $V$ and the intermediale jupul aggregate $G$ is assumed to exhibit constant relurns to scale, as is the aggregator $G$ for sle intermediate inpuls $E$ and $M$. In the competitive case, we slso foilow Goulder in assuming constant rcturns to scale for the value added production function $V$. However, in the case or imperfect competilion, and lience output prices higher than marginal cost in equilibrium, constant returns to scale would, again, imply slic existence of pure profits. We do not wish to let such profits exist, at least not in the long-run stendy-stale growtl patt. IJence in the case of imperlect compctition, we assume an increasing returns Ledinolog;; so that average costs in excess of marginal costs can reconcile market power with free entry, as ill Clanutserlia's celebrated model of monopolistic competilion. As in Rotemberg and Woodford (1992), we 
do this by assuming a value added production function of the form

$$
V(K, H)=F(K, H)-\Phi
$$

where $F$ is homogeneous of degree one, and $\Phi$ is a positive constant. (We may assume that 4 applies equaily in the competitive case, but with $\Phi=0$ ) The constant $\Phi$ indicates the presence of fxed costs (overhead), while the homogeneity of $F$ implics that marginal costs are independent of scale.

We assume that $z_{k}$ grows exogenously at a rate $g>0$. The tax changes liat we consider below will all be anaiyzed in terms of perturbations of the equilibrium around a steady-ghate balanced growth path that the economy would follow in the absence of the tax changes. Along this balanced-growth path, the aggregale capital stock, energy inputs, materials inputs, and non-energy output ail grow at the same rate $g$ (the exogenous rate of technical progress), while aggregate hours worked remain constant (so that the ellective labor input $z_{1} H_{1}$ grows at the same rale as the other factors). ${ }^{7}$ In order for fixed costa to remain a constant fraction of total costs along this balanced growth path, it is necessary for us to assume (in the case of imperfect compelition) that the number of firms $N_{1}$ grows at the same rale $g$, so that the scale of production by each firm remains constant. We assume that entry is through the introduction of new differentiated goods, so that the degree of market power of each fitm remains the same (again, as in Chamberlin's model). The details of the process of entry and the condilions needed to ensure that our steady stale with entry bas zero profits are considered in Appendix 1.

We consider only symmetric equilibria in which the production plant of all fitms are identical, so that $Y_{t}^{i}=Y_{1} / N_{1}, E_{t}^{i}=E_{\mathrm{t}} / N_{\mathrm{t}}$, and so on, where the variables without $i$ superseripts refer to aggregate quantities for the private non-energy sector. The maximization of profits by thee individual firms implieg, as before, that the marginal product of each factor is equal to the product of this factor's real price and the markup of price over marginal cost. While there are four conditions of this type, we will mainly be interested in the one that is analogous to 2 . This condition relates to the marginal product of $G$ and requires that

$$
Q_{G}\left(V_{\mathrm{r}}, G_{\mathrm{r}}\right)=\mu_{\mathrm{r}} p_{G}
$$

where $p_{G}$ is a price index for the aggregate $G_{3}, \mu_{4}$ is the common markup of all firms in a symmetric equilibritan. The price index $p_{G}$ depends on the prices of energy and materials relative to the price of

\footnotetext{
i In asstuning a balanced growth path in which (per caplita) hourz worked remain constant, we follow numerous papers in

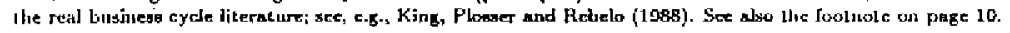


non-energy output. In a symmetric equilibrium the price of this output is the same for all firms, even in the case of imperfect competition. Because cach firm's materials are some other non-energy firm's output, the frice of maherials inputs is identical to the price of non-energy output. Energy inpuls are ansumed to be in perfectly elastic supply at a fixed relative price $p_{E}$ (which we imagine to be fixed on a world martet, and so independent of changes in tax policy and production plans in the U.S.). Thus, $p_{G \text { i }}$ depends only on the tax tate on energy, $\tau_{t}$, whose effecta we wish to analyze. Because we assume that $p_{E}$ is fixed in all of our experimenta below, there is no distinction beiween the case of an ad valonem tax and a gpecific tax auch as the BTU tax that was recently proposed.

In our simulations, we consider three different types of product market structure for the non-energy producers. In the case of perfect competition, equations 5 holds with $\mu_{i}^{i}=1$ at all times. In our second model (the "constant markup" model), it holds with $\mu_{t}^{i}=\mu$, a conatant greater than 1 , at all times. This corresponds to a model in which firms are monopolistic competitors, with the equilibrium markup being determined by each firm' elastieity of demand, which in turn follows from the elasticity of substitution between the differentiated goods. ${ }^{\theta}$

Finally, in our third and most complicated model (the "variable markup" model), we assume that firms. belong to oligopolies that mainlain high price through the threat of reversion to low prices if anyone deviates. [Rotemberg and Woodford (1992) show that this implies that the matkup $\mu_{i}^{j}$ cor each firm in industry $j$ will iw related to the ratio of expected future profits to current sales. In particular, the markup will be given by

$$
\mu_{1}^{j}=\mu\left(X_{i}^{j} / Y_{1}^{j}\right)
$$

where $\mu(A / Y)$ is an increasing tunction, $Y_{i}^{j}$ denoles the common output of each firm in the indugtry, and $X_{i}^{j}$ denotes the expected presenl value of future profits gross of fixed cosis for each firm in the industry assuming I lit collusion is maintained. Itigher expected future profits relative to current sales raise the expected losses from a breakdown of collusion relative to the polential gains from undercutting the olher firms in one's industry at the present time. The result is that collusion is easier to sustain. The formal definition of $X_{i}^{j}$ cals be found in Rotemberg and Woodford (1991) where we explain low $X$ depends on the possibility that

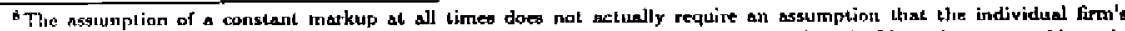

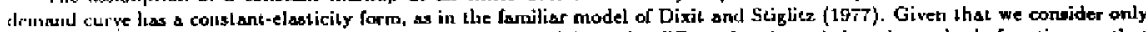

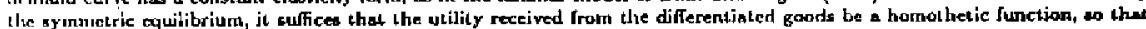

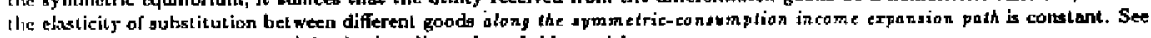
lioteniberg and Woodford (1991) for futher ditcussion of ulis model.
} 
oligopolies will either be dissolved or renegotiate their collusive arrangements.

We now describe the rest of our simulation model. To model the supply of labor and capital, we asgume the existence of a represenlative household that seeks to maximize

$$
E\left\{\sum_{i=0}^{\infty} \beta^{t} U\left(A\left(C_{i}, E_{i}^{h}\right), H_{i}^{i}\right)\right\}
$$

where $\theta$ is a constant positive discount faclor, $C_{8}$ denotes consumption purchases of non-energy output

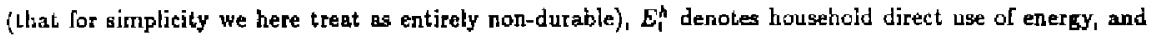
$H_{i}$ denoles tots hours worked (both for the private sector and for the government). The representalive lousehold is assumed to be a price-taker in all markets, and to face the wage $w_{4}$ lor all hours supplied, and the after-tax price of $p_{E}\left(1+\tau_{1}\right)$ for energy. (In some of our simulaticns below, we allow the tax on direcl household energy use to differ from the tax on energy inputs to production.) The bouselold atso arcumulates the capital stock (the purchase price of which is the same as the price of consumption goods), and receives the rental rate $r$, on its eapital holdings; and it owne all firms and receives the profitg from both non-energy and energy production. Cepital holdinge evolve according to

$$
K_{1+1}=I_{1}+(1-6) K_{1}
$$

where $I_{1}$ are period $t$ investment purchases of non-energy output, and $0<\delta \leq 1$ is a constant rate of depreciation.

In order to allow the existence of a balanced growth equilibrium in the case of a constant level of energy tax, we require as well certain homogeneity assumptions on household preferences. Specifically, we assume that the aggregator function $A(C, E)$ for houschold expendilure is homogeneous degree one. We also assume liat the utility function $U(A, H)$ satisfies certain homogeneity assumptions explained further in Appendix II. These imply that if the household is faced with a reaj wage that grows at a constant rate and a constant rate of return on savings, it will choose to supply a constant number of thours, and to consume a quantity that grows in proportion to the real wage. ${ }^{9}$

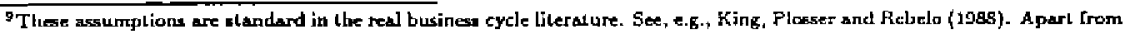
their analylical convenience, in ellowing w to andyze a alendy-stale balanced gtow Lh palh despite the exiskence of lechniça

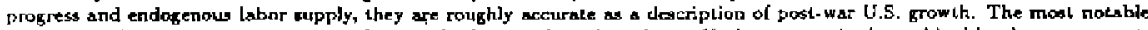

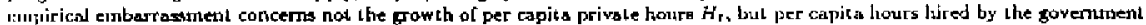

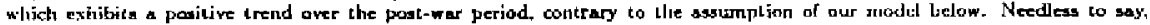
adequitely dealing with the growth of the govemment aector alserved over this period, if lakell lo represent a genuine fong-nun I reitd, would be inconpatible with tle exigtence of bslanced grawtin.
} 
As noted above, we assume that the aupply of energy is infinilely elastic to that the relative price at which energy is supplied is fixed exagenously. This is probably not otrictly correcl. However, the view that the elasticity of supply is large is jugtified to some extent by the fact the price of oil is determined in a worid market where the U.S. consumes only a quarter of world oulpul. ${ }^{10}$ Thus, even assuming that toreiga demand is inelestic, the elasticity of supply faced by the U.S. in four times the world elasticity of aupply. In addition, the foreign elasticity of demand also renders the effective supply of energy to the U.S. mare price elastic. Put differently, any reduction in price brought aboul by a reduction in U.S. consumption would raise consumption elscwhere and thereby dampen the required fall in price. The reault in that, even if the elasticity of the world supply of oil is zero, the effective elasticily of supply for the U.S. would equad three timea the clasticity of demand of all the other nelions. On the olher hand, we abstract here from considerations of international trade by supposing that all U.S. energy usage (the sum $E_{t}+E_{i}^{\text {h }}$ ) is oupplied by firms that are owned by the same representative household referred to above. "We also ignore for simplicity the use of lactor inputs in energy produetion, and treat the revenues of the energy sector as pure rents (distributed as profits to the represenlative houlehold).

We do take account of the consumption of real resources by the government, although in our gimulations, government demand is assumed to simply grow deterministically with the rest of the economy. Specifically, we issume an exogenously given path [or real governmenl purchases of non-energy output $\left(G_{1}\right)$. In order to make possible a balanced growth path, we assume that $G_{t}$ grows at the rate $g$ of labor-augmenting technical progress. Wo similarly assume an exogenously given path for government purchases of peoples time. In order to make possible a balanced-grow th path of the kind described above, we assume that the hours per capica purchased by the government are a constant, $H^{g}$, at all times. We aiso assume that lump-sum taxes or Lranslets make up for any discrepancy in a given period between the value of government expenditure $C_{\mathrm{r}}+w_{i} I^{g}$ and the vaiue of energy lax revenues $\tau_{l}\left(E_{t}+E_{t}^{h}\right)$. This allows us to consider the effects of a cliangc in the level of energy taxes while abstracting from the eltects of changing other distorting taxes or of changing government expenditure patterns. Alarket clearing in the non-energy sector then requires that

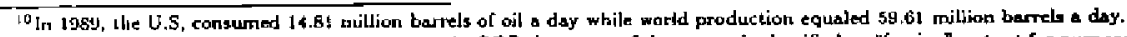

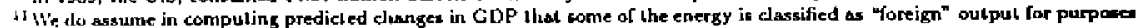

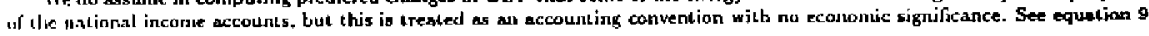
luclisw.
} 
at eacl: time

$$
C_{1}+I_{1}+G_{t}=Y_{1}-M_{1}
$$

while market clearing in the labor market requires that

$$
H_{\mathbf{1}}+H_{\mathbf{i}}^{\boldsymbol{j}}=H_{\mathbf{i}}^{*}
$$

In our numerical simulations, we consider the comparative dynamics agsociated with deterministic petlurbationg of the expected time path of the energy $\operatorname{tax}\{\pi\}$. In the case of perturbations that are amall enough, the effects are essentially linear in the percentage tax chatge. The magnitude of these linear effects can be oblained from a log-linear approximalion to the equilibrium condilions of the model, We carry out thig linearization around the long-run steady-state balanced growth path to which the economy eventually converges. This allowg us to atate our reaults in terms of the percentage changes in non-energy output and so on per perent increașe in the energy tax. It also means thal the parameter values required in order to obtain numerical results are simply elasticities of the various functions introduced above, and average values of the varjous quantities. The parameter values used in our simulations are listed in Table 2. The sources of these numerical values, as well as the interprekation of the paramelers, are discussed further in Appendix II.

In our basic simulation, we consider the effects of an permanent increase in the energy tax $T$, that is announced (unexpectedly) at the ame time that it takes effect. We assume that the econorny had previously converged to the steady-stale balanced growth path assocjated with (Je previous leve] of the energy tax (zero), and consider the path by which it converges lo a new long-run steady siate following the cluange. We also consider, for purposes of comparison, an experiment in which only the tax rate on direct houschold use of encrgy is increased, with no change in the lax on uses of encrgy as an inpul to non-energy production. In this case, the relative price of energy inputs in production continues to be $p_{E}$, while the relative price of energy for household use becomes $p_{E}(1+\tau)$. This comparison is of intercst because the gasoline tax that was eventually passed as part of the 1994 Budget is, effectively, a lax that falls disproportionalely on the energy purcliased by households. It is thus of interest to compare the elfoct of such a tix to those of a more hroad-based Lax, such as the BTU tax originally proposed by President Clinton. As might be expected, we will slow that imperfect competition increases the outpul losses associated with an energy tax only in the case of a tax on tie use of energy in production. The reason is that imperfect competition alfects the degree 
to which output falls only by affecting the energy purchases of firms.

\section{Long-Run Effects of a Permanent Energy Tax}

Table 3 summarizes the changes in the long-run levels of several variables, for each of four cages. The two types of tax ehanges considered are a shift from zero energy tax to a $1 \%$ tax on all energy use, (first two columns) ${ }^{12}$ and a shifl from no energy tax to a $1 \%$ tax on the direct use of energy by hovecholds (last two columns), assuming no lax on industrial uses of energy. Each tax change is considered for two alternative assumplions about product market strueture. In the "competitive" case (left column of each pair), we assume perlect competition (i.e., $\mu=1$ ). In the "market power" case (right column of each pair), we assume imper [ectly competitive product markets, with the typieal firm possessing market power anficient to lead it to set prices $20 \%$ higher than its marginal cost of production in the steady-state equilibtium (i.t., $\mu=1.2$ ).

As was noted above, our specification of a value for the ateady-state markup $\mu$ also determines our specification of the degree of increasing returns in the production technology. In the "competitive" case, we assume conslant returns to acale $(\phi=0)$. In the "market power" case, we assume the existence of increasing returns due to the presence of fixed costa ( $\boldsymbol{\Phi}>0)$, and endogenous deicrmination of the number of firms (and hence varieties of differentiated goods). Thus in this case there exist increasing returns such Lhat average cost is $20 \%$ higher than marginal cost for the typical firm in the steady-state equilibrium. All ot lier parameters are calibrated in the same way in the two cases.

One issue that arises at this point is whether a markup of 1.2 is reasonable. There are essentially two sources of information on this parameler. The first stems from the large literature which at tempts to meegure Whe elasticity of demand facing individual producls produced by purticular firms. This literature is relevant because it is never profit maximizing for a firm to set its markup lower than one over one plus the inverse of 1.) clasticity of demand tor its product. There are many estimates of the elasticity of demand for particular products in the marketing literature. Tellis (1988) surveys this literature, and reports that the nedian measuced price elasticity is just under 2. Thus the markup would equal at least 2 if this sample of firms is rcpresentative, In practice, elasticities of demand undoubledly difter actoss producto and the elastieity of dellnuld of llose produets studied in the marketing literature is probably alypically jow. Tluis is because the

\footnotetext{
12 Although we astume here an initial atendy atale with no energy tax, the reault would he similar in the case of a lof increace

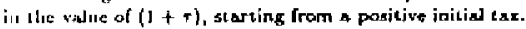


marketing literalıre focusea on the demand for branded congumer products which are nore differentiated Than ubbrandod products so that their demand is probably less price sensitive. Thus, the typical product in Lise econony probably has a price elasticity of demand that exceeds 2 .

A second approach is to analyze what happens to revenue and costs in response to an exogenous change in aggregate demand. A particularly simple vergion of this approach has been proposed by Hall (1988, 1990). Ile studies the degree to which the increase in GDP generated by increaseg in exogenous variables guch as changes in military purchases is accompanied by an increase in costs. Insofat GDP increases by more than costs, the markup is grealer than one. His estimates indicate that the markup $\mu$ is between 1.4 and $1.6,13$

There is also a re]ated literature which tries to obtain econometric estimates of marginal cost and, in some cases, conbine them with econometric estimates of the elasticity of demand. The aim of this approach is to obtain sinultaneous, independent estimates of the markup and of the degree of increasing returns. Morrison (1090), for example, estimates a flexible funclional form cost function, using data on gross industry output and materials inputs. Her estimates of that markup $\mu$ tange between 1.2 and 1.4 for 16 out of her 18 industries. One notable feature of these estimates is that her industry estimates of the ratio of average to marginal cost closely resemble her estimates of the markup itself. Thus the relation between these two parameters that we imposed through our zero profit condition appears to be validated.

Because we are considering only long-run effects, the results do not depend on whether the tax increage is immediate or phased in over a period of time; only the eventual permanent increase in the tax rate mat ters. Similarly the resules do not hinge on whether the long-run substitutability of factors of production exceeds their slırt-run substitutability; only the long-run substitution possibilities matter here.

Furthermore, the "market power" case reported in Table 3 refers equally to the monopolistically competitive model and to the oligopolistic collusion model. The reason is that in neither case does the energy tax change have any efleci on the markup of prices over marginal cost in the long-run steady atate. In Whe case of monopalistic competition, the markup is predicted to be a constanl, determined solely by the elisticity of substitution between alternative diJerentiated goods. In the oligopolistic model, by contrast. the markup depends upon the ratio $X / Y$, and so can vary in response to policy changes. However, in a

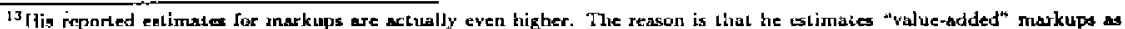
opposed lo the more elandard markep of price arer lotal marginal cost. For a discussion of the relation between the iwo, sec Hoteunbers and Woodford (1992).
} 
stcady-state equilibrium, the present discounted value of profits $X$ is proportional to $Y$. Moreover, while the steady state value of $X$ also depends on the steady-atate real rale of interest, $r$, this real rate of interest is solely determined by preference parameters and the exogenous rate of growth (see Appendix II). Hence the steady-state $r$ is uraffected by the energy tax, as a regult of which gteady-state $\mu$ is also unaffected. Thus the long-run effects are the same in either type of imperfectly competitive model; all that matters is the size of the steady-atate markup $\mu$.

We now turn to the numerical results reported in Table 3. In esch row, the figure reported repreaents the percentage change in the long-run value of that variable resulting from a $1 \%$ energy tax. (In our log-linesr approximation to the equilibrium, the eflects of a $k \%$ energy tax are obtained by multiplying each of these unumbers by 1.) The variables, of course, grow over lime in the steady-8tate equilibrium; but the steady-state growth rate is unaffected by the energy tax (as it is determined solely by the exogenous rate of technical progress). Thus the figure -.071 for non-energy output means that output is -.071 percent bower at all times than it otherwise would have been, in the new long-run steady-state growth path. "Non-energy output"

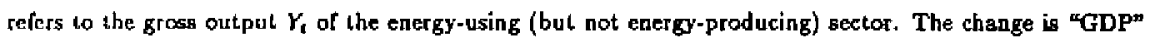
is computed as

$$
\Delta Y_{1}-\Delta M_{\mathrm{f}}-P E \Delta E_{\mathrm{T}}+\theta^{d e m} p E\left(\Delta E_{1}+\Delta E_{\mathrm{t}}^{h}\right)
$$

where $\Delta$ indicales the difference (not percentage difference) in value of the equilibria between the perturbed and umperturived equilibria, and $\theta^{d o m}$ denotes the share of energy tsed in the U.S. that is dornestically produced. 14 Thus the GDP measure aggregates value added in the non-energy sector and the domeatic eitergy-prorilucing sector, where for simplicity the tolal revenues of the latter sector are counted as value ildec. "Jlours worked" denotes total hours worked $H_{4}$; because government hours are assumed to follow an exogenous path unaffected by the energy lax, the reported decline in hours is only $83 \%$ of the size of the decline ill hours in the private non-energy sector. The "product wage" refers to the wage deflated by the price of non-energy ingut (i.e., the quantity $w_{1}$ in equation (3a)), while the "consumption wage" refers to the wage deflated instead by the price index $p_{A 1}$ of the household consurption basket,

$$
p_{A t} \equiv \frac{C_{1}+p E\left(1+t_{1}\right) E_{1}^{h}}{A\left(C_{1}, E_{\mathrm{t}}^{\mathrm{h}}\right)}
$$

\footnotetext{
1' Inplicilly, we ascume liere I laal U.S. energy production varies in the shme proportion as U.S. energy use.
} 
"Energy use in production", "capital stock" and "number of firms" reler to the variables $E_{l}, K_{t}$, and $N_{t}$ introduced in the previous aerion; all refer solely to the private non-energy sector. The number of firms is indeterminate in the competitive model.

A striking fenture of the reoults in Table 3 is that a tax that is levied only an direct household purchases of energy has no effect whatsoever on equilibrium activity in the private non-energy sector. Household energy use falls, and the consumption wage falls becauge the price index $p_{A}$ rises. However, the household does not change its supply of labor or demand for non-energy goods, nor does the equilibrium product wage in the loll-energy sector change. GDP fals only because of the reduction in domestic energy production due to reduced household use of evergy. 15

Two lealures of our model account for this result. The first is that we made assumptions that ensured the existence of a steady state where the economy grows but hourg worked do not. Since output, consumption, energy purch ases and wages all grow at the aame rate in such a sleady state, we require that equiproportional increases in wages and the aggregate $A_{1}=A\left(C_{1}, E_{1}^{h}\right)$ be consistent with an unchanged quantity of labor supplied. ${ }^{16}$ A permanent increase in the tax on housebold energy raises $p E\left(1+\tau_{i}\right)$ and thus raisen the consumption defiator $p_{A 1}$ while it lowers the consumption wage. As long as $A_{1}$ falls in exact proportion to the increase in $p_{A}$ while the product wage is unaftected, the fall in the real wage and in consumption are equiproportional so the quantity of labor supplied does not change.

The second important source of this result is our assumption that the household's clasticity of substitution between non-energy consumption and direct energy use is equal to 1 . We hase this on the unit elasticity of dealand estimates of Houthakker, Verleger, and Shechan (1974). This means that the shares of hougehold cxpenditure on energy and non-energy output will remein constant in the face of a chauge ir: the relative price of these two kinds of goods. But supposing that the path of $p_{A 1} A_{l}$ is unchanged under the circumstances just described, it lollows that the paths or $C_{i}$ and of $p_{E}\left(1+\tau_{1}\right) E_{t}^{h}$ are unchanged. Thus household energy use falis in inverse proportion to the Lax incresse, whiie non-energy consumplion demand and labor supply are unclianged. This means that, if the product wage and the real rate of return are unaftected, consumption demand and labor supply are tnchanged so that output in the non-energy sector can remain constant as

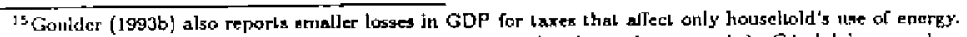

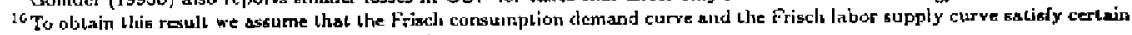
frotıogeneily properties explained in Appendix II.
} 
well. This in turn implies that the previous paths of the product wage and the real rate of interest continue to describe an equilibrium. This argument applies whether there is perfect competition or not ajace the two Irodels difter only in the way non-energy firms react to changes in their environment. But, we wust asw a Lax on household use of energy does not affect this environment.

Since the tax on hougehold direct use of energy has no effect on non-energy autput, the effects on output o! a tax on all energy ere due to the tax on the industrial use of energy. The effects would bave been just as large if onlty the energy used in production were taxed. It is true that the reault of exactly zero effect of the tax on direct hougehold use dependa upon particular paraneter choices that might well be challenged. [lowever, for any values near ours, the result will still be approximately true - the effects of a tax on hougehold eliergy use will be much smaller than the effecis of a tax on industrial uses, and indeed the effects of a tax oll household energy uge could as easily be expansionary as contractionary. Thus the obift from a "BTU Lax" to a gasaline Lax in the budget that was eventually pased by the U.S. Congress probably resuited in a lax that places less of a burden on the economy, per dollar of revenue raised. Another implication is that ill designing a tax intended to reduce carbon dioxide entissions, a tax ained mote at household energy use is likely to contract economic activity less, for any given Ieduction in emissions that is achieved, than one lased simply on the "carbon content" of various fuels.

Now consider the eftects of a tax on all types of energy use. Private non-energy production contracts, as do hours worked, the energy used in production, the capilal stock and the real wage deflated by the price of non-energy output. The contraction in hours siands in contrast to the case of a lax on energy consumption only. Jt comes about because a lax on all energy lowers the consumption wage by more than it lowers $A_{f}$. The labie-shows that GDP falls by slightly more than does non-energy output in this case. The reason is Ihal the contraction of the energy sector is even more severe, in percentage terms, than the contraction of the private non-energy sector. In the imperlectly competitive case, there is also a reduclion in the long-run tumber of firms, due to exit in response to profits no longer large enough to cover the fixed costs.

liven in the competitive ease, the output lost as a result of the energy tax is tather significant. Since the share of folal energy expenditure in GDP is 0.066 , a one percent tax increase raises government revenues lis only a66 percent of GDP. On the otlier hand, GDP is itsel[ reduced (it the long run) by .071 percent. 
17 The ratio of oulput loss to revenue raised is even more severe if one considers the case of a pure tax on industrjal uses of energy. In this cage, a one percent energy tax raises government revenues by only, 040 percent of GDP, while GDP is reduced by .050 percent. 18

But the contractionary effects of an energy lax are even greater when one allows for imperfect competition. In the case of market power, the long-run decline in non-energy output is .097 percent, and the long-run decline in GDP is 098 percent. Thus even a relatively modest degree of market power (prices $20 \%$ above marginal cost) significantly imcreases the predicled effect of the energy tax; the long-run non-energy output decline is increased by a factor of nearly 1.4 .

The reason for this can be understood by analyzing equalion 5 in the same way that we analyzed equation 2 in section 2. It follows [rom 5 that a value $\mu>1$ implies a higher estimate of the elasticity of the aggregator $Q$ with respect to $G$. Using the shares reported in Table 2 , the implied value of this elasticity is increased from 52 to .624 (a faclor of 1.2 ) by raising $\mu$ to 1.2. The elasticity of $Q$ with respect to $V$ similarly falls Irom .48 to .376. Furthermore, as in section 2 the higher value of $\mu$ implies that the fall in $G$ is larger in response to a change in the price PG. It turns out that, for fixed $V$, the fall in $G$ is inversely proportional to 1.he elasticity of $Q$ with respect to $V$, and thus is larger by a factor of 1.28 when $\mu=1.2$. Thus, supposing that the index of primary inputs $V$ were nol affected by the energy tax, $G$ would have to fall by 1.28 times as mucl, and so output would fall by $1.53(=1.2 \times 1.28)$ times as much, in the case of market power. In fact, the difference between the output declines in the two cases is not so extreme in our simulations. This is because $V$ actually falls more in the long run in the competitive case. Nonetheless, the contraction is significantly larger in the presence of market power.

The energy tax also has significantly greater adverse effects in the case of market power in severa] other respects as well. For example, the real product wage [alls by more than 1.5 times as much in percentage

\footnotetext{
${ }^{17}$ This ratio of the oupput toan to the revenue raised is comparable to what is implied by the reaults of ather authors. For example, Goulder (1992) estimales that a 525 (in 1990 prices) per ton tax on carbon centent will reduce real GNP in 2020 by an

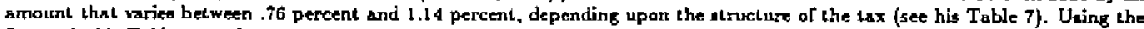

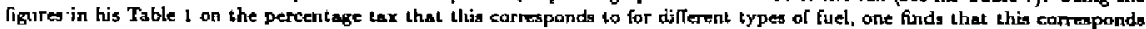
In an average tax race an energy use of 14.5\%, so that the revenues rajsed should be oniy approximately got percent of GNP, rew isnoting the reduecions in the eosk share of enesgy that blould Jollow from such a avere ex. Goulder (1993b), on the wLher hand, repprta maller GNP losses. He conviders a Lax of 45 tents par siblinn BTU's which corresponds roughly Lo a $27 \%$ lax on energy and eomputes a reduction in GNP of ordy a thind of one perrent. By contrast our ealimales would imply that a $22 \%$ tax would lead to GDP lowes of $t .5$ perment.

18 Non-uergy oxtput still fadts by .071 perent in this case, but the energy sector contracts to a inneli smaller extent. Total

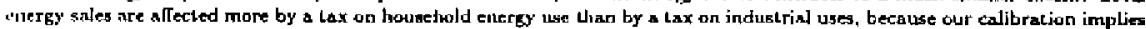
that energy is more substitutable for other goods for hatesthalds than for firmis.
} 
terms. This indicates a more significant contraction of labor demand; the only reason that hours worked do not fill more is that households are willing to accept the lower real wage because of their lower wealth in Wis case.

\section{Short-Run Effects of Changes in Tax Policy}

III Ilis section we begin the more complex analysis of the short-run effeets of ehanges in policy. We focus luere on the transition to a new long-run steady atale consialeat with a new permanent iax rate. During this transition the elfecls of lax rale clianges differ depending on whether markups are conslant or not. We thus consider separately our two models of imperrect competition.

We consider here an unexpected permanent increase in the energy lax rale $\tau$ from zero lo 01 that takes effecl immediately. Since the tax change is ool anticipated in advance, we suppose the economy sterts out in the steady-slale balanced growth palh associated with zero energy taxatjon. We imagine that the tax applies to ail uses of energy, although as explsined in the previous bection, the eflects of the tax on the non-encrgy sector tollow solely from the taxation of energy used as an input to non-energy production. ${ }^{19}$

Figure 2 displays the transitional effects on non-energy output, under the three alternative specifieations of product market structure. The vertical axis indicales percent age devialions from the previous ateady-state growlh path; $-10 \times 10^{-1}$ mears a reduction of 10 percent. The horizonial axis indicates the year; year 0 is the year in which the tax change is arnounced and takes effect. In the competitive case, the tax lowers non-energy oulput by .071 percent in the long-run as we showed in Table 3 . We now see the short-run effects as well. In the first year, non-energy output is already reduced by 058 percent. In subsequent years, output contimues lo fall further below the previous trend path ${ }_{s}$ as the capital stock is eroded; but a large part of the eventual output decline occurs immediately. In the case of the constant markup model, the general picture is similar. But, as the elasticity or output with respect to energy inpuls is larger in this case, the decline in output is larger both in the short run and in the long run.

In ilue case of the variable markup model, the lorig fun eflects are the sime as for the constant markup model. As explained in the previous section, bolh models predict a long-run reduction of non-energy ontput.

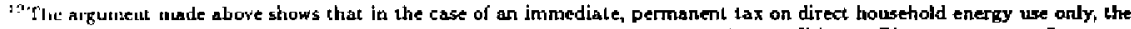

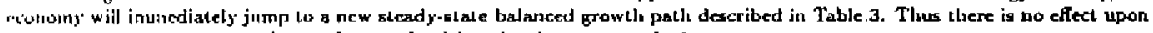

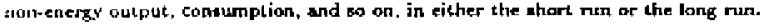


by .097 percent. However, the ohort run effects are quite diTerent. During the first year of the energy tax the constant markup model prediels a reduclion by .083 percent, while the varinble markup model predicts a reduction by .123 parcent. The predicted short run eftect is almost one and one-tialf tirues as large (and thus is more than twice the oize of the effect in the competitive model). This is because the variable markup model predicts that the markup increses when the energy tax is increased, and then gradually returns to jts original level over time. The markup increases because the ratio $X / Y$ increases. This occurs, in the first instance, because of decline in real interest rates that results from the reduced returns to capital (which eventually return to notmal as the capital stock is reduced). Lower real inlerest rates menn that the expected future profits trom collusion are discounted to a lesger extent, making a greater degree of collusion possible. Higher markups then themselves contribute to a higher ratio of profits to sale each period, making $X / Y$ still higher and so helping to raise markups further. Higher markups also lurther reduce the returns to existing capital goods. Thus lowers real rates of return futher, thus further raiging $X / Y$ and further raiging merkups in a self-reinforcing process.

In our simulation, the markup increases by ,011 percent during the first year of the Lax (1.e., from 1.2000 to 1.2001 ). Even this amall increase in the inefficiency wedge due to firms' market power has a sigaificant effect on the predicted equilibrium allocation of resources. To understand thig, it is helpful to suppose first. that labor supply is inelastic. Then, $V_{r}$ is entirely As a result, 5 defermines $G_{1}$ as a function of $\left(\tau_{t}, \mu_{t}\right)$. Then, using $3, Y_{1}$ depends only on $\left(r_{1}, \mu_{r}\right)$. Now let us investigate for a given increase in $\tau_{i}$, the quantitative efTect of a an increase in $\mu_{t}$. Because energy costs are only aboal $4 \%$ of total inlermediate inpul exsL, a one percent increase in the after-tax energy price raises the price index $P_{G}$, by only .04 percent. Thus a contemporaneous 011 petcent increase in the markuf means that the right land side of 5 increases by 1.3 times as much (in percentage terms) as it would in the case of a constant markup. In our log-linear approximation to the solution, the percentage decline in $Y_{t}$ is proportional to the percentage increase in the rigltc hand side of 5 , and so il should be $\mathbf{1 . 3}$ limes as large in the variable markup case.

In our simulation model, we also allow for endogenous habor supply. 20 In this case, bouseholds reduce labor supply rather than accept a real wage cut of the size that would be required to induce firms not to

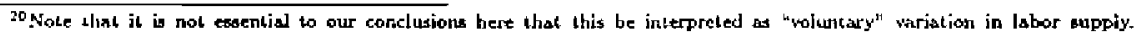
Qualitalively sinilar condusions would be obsailed in the caste of nuy source of slorl-run "reak wage rigidity", due for example to pre-existing wage contracta or to efficiency wage corraideralians.
} 
reduce ilue labor inpuls that they use. Thus non-energy oulput fals even more than it would in the case of itelastic labor supply. This effect is present regardless of product market atructure. llowever, one can ensily see that the real wage decline requised to induce firme not to reduce labor inputs is larget if the markup rises. For it followe from 5 that if the markup rises, the value of $G_{1}$ fall more, and hence that $Q_{V}\left(V_{t}, G_{t}\right)$ for fixed labor and capital inputa falls more. On the other band; the same logie that leads to 5 impliea that Whe real wage must equal $Q_{V} V_{H} / \mu$. The fall in the real wage is thus magnified both by the inerease in $\mu$ and by the severity in the fall of $Q_{V}$. It thus makes mense that in the case of endogenous labor aupply, the effect of the markup increase on outpul is even greater. It is the fact that such small changes in the markup cali malter so much for the size of the predicted effects of the tax increase that leads us to insist upon the importance of produet market structure for tax analyses of this kind.

\section{The Effect of Expected Changes in Energy Taxes}

Up to this point we have considered the effect of unanticipated permanent increases in energy taxes. There are several reasons, howevet, for energy taxes to be anticipated. First. there is a time gap between the mornent where tax policy is announced and when it takes effeet. In particular, the Clinton proposal called for a gradual phase-in or the BTU tax. Second, tax changes are not necessarily permanent. Any particular tax, such the energy tax has some probability of being repested in the luture.

We start by considering the case of gradual phase-in. We thus report simulations in whith the energy tax is increased by one-half of one percent in the year that it is announced while the full one percent tax applies Irom the second year onward. The comparison with the case of an instantaneous increase in the tax is illteresting in part because a gradual plase-in was actually proposed. Moreover; as we will show, the effect of this gradual phase in depends even more crucially on product market structure than the eventusl effect of a permanent tax.

The consequences for non-energy output are shown in Figure $\mathbf{3}$, for each of the possible market struclures. $A:$ olic mightit expect, output [alls by less in the first year than if the [ull tax were to take inmediate effect. III Fact, in none of the imodels is the contraction in the first year even hall the size indicated in Figure 1. In Whe chise of the competitive model, the first-year decline in non-energy oulput is only .016 percent; in the ronstant markup model $]_{T}$ it is only 012 percent; and in the variable markup model, output does not decline 
at all in Lle first year, but instead rises by .0Il petcent.

Ote reason for the first year effect to be so muted is that the wen!th effect on labor supply, which tends to increase equilibrium output, is nearly a large in these simulations as in the previous ones. On the other hand, tlie current increase in energy costs, which tends to reduce equilibrium output, is only half as large. The other important factor, in the case of the variable markup model, is that expectalione of future profits ate reduced nearly as much as in the previous simulations, while current sales are reduced by much less. Tinis means that the ratio $X / Y$ falls, so that the equilibrium markup is temporarily reduced in the oligopolistic model. The palh of the equilibrium markup in the oligopolistic model is stown in Figure 4, for the cases of the inuncdiately effective tax and the phase-in over a one-year period. In the case of the gradual phase-in, the markup fals by about .004 percent (i.e., , from 1.2 to 1.19995 ).

After ble first year, the path of outpul in these simulations is similar to the one we derived for an immediate tax increase. The only difference is that the higher output in year 0 is associated with a higher leved of investment. Thus the capital stock in year 1 is higher. In lact the econony now begins year 1 with a slighlly larger capital stock than in the original balanced-growth path in all cases. By contrast, the capital stock was slightly lower in each of our previous simulations. In the case of the compelitive model and the constant matkup model, the higher capilal stock means that the output decline in year 1 and later is not quile as large as in the previous simulations. On the other hand, in the case of the variable markup model, we find tlat a ligher capital stock actually makes the output decline even more severe. The higher capital stock implics that real jnterest rates are even lower. This implies that $X / Y$ is even higher and thus leads to even higher markups. Figure 4 shows that, jndeed, the markups in year 1 and later are actually greater in Ile case of i pliased-in tax.

Finally, we report simulations in which the lax increase is not expected to permanent. We now suppose that the tax is increased to $1 \%$ on all uses of energy, but that it is anticipated that each year there is a $20 \%$ probahility that the tax rate will be permanently restored to its original value. In our dynamic equilibrium model, the effects of a tax increase cannot be analyzed independently of expectations about future policy, and it is iraportant to realize that economic agents need not expect that a tax change is permanent simply ixratise llie bill that is enacted does not specify a future date it which it beconves invalid. Here too we find that the effects of an expectation of future policy reversal chepend greally upon our assumptions about 
jroduct market struclure.

Figute 5 presents the time palh of non-energy oulput in the case of the three possible market structuret. Hore what is plotted for each year is the level of non-energy output in tlat year relative to the previous I rend growth path assuming that there has been no reversal of the tax up until that Lime. In the cage of both the competitive model and the constant markup tnodel, the contraction of non-energy output is greater lian it would have been were the tax expected to conlinue lorever. This is due to the wealth effect on labor supply; oplimism sbout seversal of the tax makes households expect higher future incomes and thus makes them less willing to work in the present. This demongtrates that the contractionary effects of energy taxes nay, in practice, be considerably greater than those indicated in Figure $1,{ }^{21}$

In the case of the variable markup model, things are more complex. It is again true that the expectation of it possible reversal lowera first period output because of the wealth effect on labor supply. However, the possibility of a policy reversal also raises the equilibrium real rate of feturn, because higher rental rater on capilal are expected in the event of repeal of the tax. This higher rate of return lowers the present discounted value of future profits relative to current revenues. The resulting reduction in $X / Y$ lowers equilibrium markup in the oligopolistic model. While the markup still rises following enactment of the tax, it does not rise as Intuch in in the simulation depicled in Figure 1. And, assuming that the tax las not yet been repealed, Lhe equilibrium markup from year 3 onward in the oligopolistic model is actually lower than that in the monopolistically competitive model. This occurs becnuse, once the capilal stock has fallen sufficiently below il: initial lcvel, the real rate of return remains consistently above the real rate associated with the initial sleady state. The consequence is that if, contrary to expectation, the tax continueg for many yearg, output in : aclually higher in the oligopolistic model than in the monopolistically competitive model.

\section{Conclusions}

Wi: hitre found that allowing for imperfect competition in product markets las an important quantitative cllcol on estimates of the eflects of energy taxes on the tevel of exonomic aclivity. Allowing for even a modest Mithac llarkip of prices over marginal cost increases the predicted decline in output which is caused by an

\footnotetext{
${ }^{21}$ Tluere are ollier reasone why one might expect the stirnulus lo babor supply fron the expeciation of low future incomes

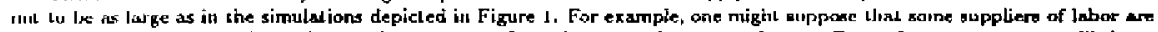

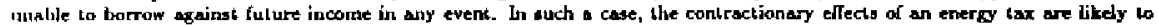
l.1 Iatere than these inclicated in those simulations.
} 
incmisor in tlic afler-tax relative price of energy inputs. And allowing for even a gmall increase in equilibrium markups, due to increased sustainability of collusion among members of an oligopoly, can greally increase the predicled oulput decline,

We have paid particular attention to a specific model of oligopolistic collugion that we have elsewhere atglled helps to explain the responses of the U.S. economy to a variety of kinds of macroeconomic shocks. This model imaplies that an increase in energy taxes may well temporarily raise equilibrium markups., especially when it is both unexpected and expected to be reversed soon with significant probability. In this case, the slort-rin contractionary impact of an energy tax is especially large. This effect is, lowever, senbitive to the precise dynamic specification of the proposed taxes. Markupa in the oligopolistic model may fall rather than rising immediately following announcement of an energy tax increase if there is a delay in the implementation of the tas.

In general, our results suggest an even less favorable relation between the revenues raised by an energy tax nuld the reduction of economic aclivily than earlier studies (assuming competitive markets) have indicated. lor eximple, in lle case of immediate implesnemtation of a 1\% energy tax that is expected to be reversed siel yeur with a $20 \%$ probability, the revenues raised in the first year of the tax will be .066 percenl of GDP, while GDP is itself reduced by 110 percent in the first yoar according to the constant markup madel, ind by 112 percent according to the variabic markup model. The GDP reduclion five years later is only .098 percent in the variable markup model if, contrary to expectalion, the tax increase has not yet been reversed'; but it is by that time 134 percenl in the constant markup model. Althougl: we do not here analyze alconative revente sources, we believe that an energy tax is reiatively unatitractive on this dimension.

Our resulus also suggest ways in which an energy tax might be struclured to minimize the contractionary elfects. Our most important finding in this respeet is that a tax solely on direct houseltald use of energy hecd not contract non-energy production at al]. Insolar as allowing for imperlect competition inereases the predicted contractionary effects of a Lax on industrial uses of energy, but does not aftect the predicted

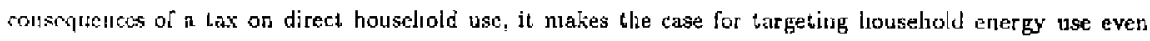
shouger.

The short-run contractionary injact of an energy $L x x$ is also reduced if the tax is phiased in gradually, Aurd our siraulations indicate that the output gained in the transition period is mucil larger Litan the reventie 
losgeg due to the gradual phase-in. In the case that we analyze here, for exarnjle, gratua? phase-in involves a reveaue loss of .033 percent of GDP in the first year relalive to the revenues from immediate implementation. Dut the result is that GDP [alls by 070 percent lese in the case of congtanl markups equal to 1.2, and by 100 percent less in the case of the variable markup model. In the case of the constant markup model, the outpal loss is adso somewhal miligated in later years a!though it is made alightly worse in the case of the variable markup model. 


\section{References}

Diimond, Peler A. and James A. Mirrlees, "Optimal Taxalion and Public Production [: Production Efficiency and [l: Tax Rules", American Econonic Review, 61, 1971, 8-27 and 261-78.

Dixil, Avinash, and Joseplı E. Stiglitz, "Monopolistic Competition and Optimum Product Diversity," American Economic Review, 67, 1977, 297-308.

Goulder, Lawrence II., "Carbon Tax Design and U.S. Industry Performance," Tax Policy and the Economy, 1992, 59-104.

"Efects of Carbon Taxes in an Economy with prior Tax Disiorlions: An Intertemporal General Equilibrium A nalysis," mimeo, I993a.

"Energy Taxes: Traditional Efficiency Eflects and Enyitonmental Implications," Tax Policy and the Economy, this issue. Other Taxes are Accounted for?" NBEn Working Paper no. 4061, May $1992 \mathrm{~b}$.

Hall, Robert E.:"The Relation Between Price and Marginal Cost in U.S. Industry," Journal of Political Economy, 96, October 1988, 921-48.

- "Invariance Properties of Solow's Productivity Residusl," in Peler A. Diamond ed.Growth, Productivily and Unemployment, Essays to Celebrate Bob Solow's Birthday, Cambridge: MIT Press, 1990 .

Jouthakker, II.S., Philip K. Verleger, Jr., and Dennis Slieehan, 'Dynamic Demand Analyses Lor Gasoline and Residentia! Electricity," American Journa! of Aricultural Economics, May 1974, 412-18.

Jorgenson, Dale W., and Peler J. Wilcoxen, Reducing U.S. Carbon. Emissions: An Econometric General Equilibrinm Assessment," Resource and Energy Economics, 15, March 1993, 7-25.

. Mdrl. Jenneth E, "The Optimal Tax on Capital Incone is Negalive," mirreo, 1993.

King, Rabert G., Charles I.Plosser, and Sergio Rebelo, "Producliou, Growtl and Business Cycles: I. The Basic Neoclassical Mcodel," Journal of Monetary Economics, 21, March 1988, 195-232.

Morrisoll. Catherine J - Market Power. Econonic Profilability aud Produclivity Growth Measurement: All Integrated Structural Approach," NBER lVorking Faper 3755, May 1900.

Olife of Technology Assessment, Congress of the United Slates, Energy Use and the U.S. Economy, U.S. Government Pinting Office, June 1990

Pindych, Robert S., and Julio J. Rotonberg, "Dynanic Factor Domands and the ETects of Energy Price 
Slocks," American Economic Review, 73, 1983, 1066-1079.

Ratrmbreg, Julio, and Michael Woodford, "Markups and the Dusiness Cycle," NBER Macroeconomics Anuval, 1991, 63-129.

- _- "Oligopolistic Pricing and the Effects of Aggregate Demand on Economic Activily," Journal of Political Economy, 100, 1992, 1153-1207.

-..., "Imperfect Competition and the Effects of Energy Tax Increases on Economic Activity, ${ }^{n}$ mimeo, A pril 1993

Tetlis, Gerald J.:"The Price Elasticity of Selective Demand: A Meta-Analysis of Econometric Models of Sales," Journa' of Marketing Research, 25, November 1988, 331-41. 


\section{Appendix I}

\section{Entry and the Elimination of Profits}

We have slated above that in the long tun, entry and exit are assumed to maintain pure profits at zero. It is straightrorward to show that the first order conditions for profit maximization imply that pure profits are zero in a symmetric equilibrium if and only if

$$
\left(\mu_{t}-1\right) Y_{t}=Q_{V}\left(V_{t}, G\left\{E_{t}, M_{1}\right)\right) N_{t} \Phi
$$

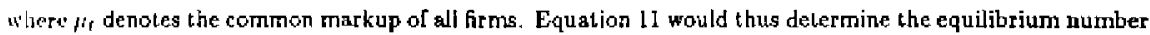
of firms each period in the case of instantaneous entry and exit. This equation refers anly to the case of imperfect competition and increasing returns where $\mu$ exceeds one and $\phi$ is strictly positive. Otherwise, as Isual with constant returns, the number of firms is indeterminate.

We do not, however, suppose that entry and exit oceur so qujckly. Because entry and exit are peripheral to our main inlerests here (and because, as long as they are slow, the exact dyamics do mot matter much for our resulta) we adopt a simple ad hoc specification rather than explicitly modeling the entry and exit decisions. Let us define

$$
\bar{N}_{1} \equiv \Phi^{-1} \lim _{k-\infty}(1+g)^{-k} E_{t}\left\{\frac{\left(\mu_{1+k}-1\right) Y_{i+k}}{Q_{v}\left(V_{t+k}, G\left(E_{1+k}, M_{1+k}\right)\right.}\right\}
$$

Thus $\bar{N}_{1}$ denotes the number of firms needed at date t, if a constant rate of growth $g$ of the number of firms ever alter is to resuit in zero profits in the long run. We then assume that the number of firms graws

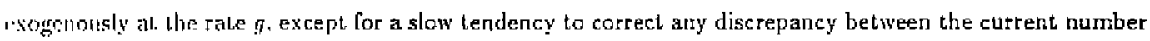

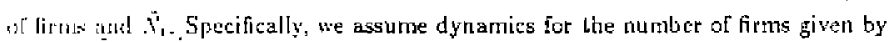

$$
N_{t}=p \bar{N}_{t}+(1-\rho)(1+g) N_{t-1}
$$

where $0<p \leq 1$ is a constant partial-adjustment rate. This specification introduces an additional predetermisicd state variable, in addition to the aggregate capital stock $K_{1}$, and that is the previous number of firms $x_{i-1}$. Nole that once there ceases to be new information aboul fitute policy, $\bar{x}_{\mathrm{t}}$ grows at the constant rate $y$, so : liat 13 implics that the percentage discrepancy between $N_{t}^{\prime}$ and $\vec{N}_{1}$ is eliminated at an exponential rate. Sulsstitution of 12 and comparison witl 11 indicales then that hhe share of pure profits in total revenues HuIs: asymploticnlyy approach zero, as desired. 


\section{Appendix II}

\section{Parameter Valueg Used in Simulation}

Ilere we explain the numerical values reported in Table 1. The steady-state balanced growth path of the econorry is described by a set of growth rates and shares, that we calibrale using the U.S. nationaJ income accounts. According to our model, the exogenous rate $g$ of labor-augmenting technical progress is also tlie sieady-state rate of growth of real GDP, which is why we asgign the value $.03 /$ year. The parameter $r$ represents the real sate of return in the steady-etate equilibrium. This is not a primitive of the model, but the model predicts that it should equal $\theta^{-1}(1+g)^{\alpha}$, 80 that calibration of $r$ is equivalent to calibration of the rate of time preference of the representative household. Following King, Plosser and Febelo (1988), we calibrate $r$ to match the average real return on the U.S. stock market. The parameter $\delta$ represents the exogenous tate of depreciation of the capital stock of the private non-energy sector. The model inplied that in as stezdy-glate equilibrium, the share of investment in final uses and the share of capital in total costs must be linked, through the relation

$$
\frac{s_{1}}{g+\delta}=\frac{s_{K}}{(r+\delta)\left(1-s_{M F}\right)}
$$

Ifence the values assumed for $g$ and $\psi$, and the share parameters discussed below, imply a value for $\delta$, which is the one given. These parameters imply a steady-state capilal-output tatio in the privale non-energy sector of 7.5 quarters, which is reasonably consistent with the rational ineome accounts as weli.

The parameters $s_{C} s_{I}, s_{G}$ represent the steady-stale shares of private consumption expenditure, private investment expeuditure, and government purchases of privale non-energy output, respectively, in total final Insus $]^{*}-W$ or primte nou-energy output. We galibrate these shares to equal the average shares of these three kinds of expenditure jn U.S. private value added (GDP minus value added by the federel, state and local govermments). The paramelers $s_{E}, s_{M}, s_{H}, s_{K}$ repregent the sleady-stale shares of energy, materials, labor and capital costs, respeclively, in the total costs of the private non-energy sector.

As we explained in section 1 , energy costs in the non-energy sector are $1.2 \%$ of value added. Hence we must have

$$
\frac{s_{E}}{1-s_{E}-s_{M}}=.042
$$

We ascume. somewhal atitharily, a share of materials costs of .5. This is somewhal smaller than the average 
materials blare indicated in the Commerce Department dala for U.S, manufacluring sectors, but we auppose Llate malerials are a smaller traction of costs oulside of manufacturing, The above equation then implies $* H^{\prime}=02$. This leaves 48 of total costs for labot and capitai costs. Insolar ag wagea account for about $75 \%$ of value added in the satjonal income accounts, we set $s_{H}=.36, s_{K}=.12$.

As is explained in the text, we assume that in the long run, the number of firms is such that equation 11 is satisfied. This implies that in the ateady state, sq, the share of fixed costs in total costs, must equal

$$
\left(1-s_{E}-s_{M}\right) \frac{N \Phi}{F\left(K_{1} z H\right)}=\frac{\mu-1}{\mu}
$$

Ilence our calibration of this parameler follows from our choice of $\mu$, discussed below. (Note that se doeg not refer to costs in addition to the four calegories previously listed. The fixed costs are a subset of the costa already counted once as labor and capital coste.)

The calculaitions just explained imply that the share $\theta^{\text {dom }}$ of total energy use that is domestically produced is .83 . They also explain why we set $\theta^{\text {h }}$, the share of tolal energy uge that is direat household use, equal to 4. The parameter $q^{g}$, indicating the steady-state value of $H^{\prime} / H^{\prime}$, is set equal to -17 , the average ratio of government employment (surnming employment by federal, stale and local governments) to iotal employment over lile postwar period.

'I'Jis completes out specification of the parameter degcribing balanced growtl. We turn next to the remaining pasameters of the production technology of the private non-energy sector. As the runctions $Q, F, G$ are all assumed to be homogeneous of degree one, the only parameters that occur in the log-linear approximalion to our equilibrium conditions are, in the case of each function, the elasticity of the function with respect to cach factor (on]y one [ree parameter per function as they must sum to 1) and the elasticity of substitution between the two factors. The elasticities of substitution enter the log-linear approximations to t.lose equitibrium conditions involving marginal products. Ail of these elaslicilies are evaluated at the factor mix that occurs in the steady-state equilibrium. The elasticities wilh respect to the individual factors are implied by the steady-state share parameters already discussed; for example, the elasticity of $G$ with respect to $E$ must equal $s_{E} /\left(s_{E}+s_{M}\right)$, and the elosticity of $Q$ with respect to $V$ musi equal $1-\mu h\left(s_{E}+s_{M}\right)$. (It will be observod that for both of the values of $\mu$ that we use, each of these elasticities is positive.) It thus remains only to specify l.he elasticities of substitulion. The values given in Table 1 for $\epsilon_{G V}$ and e em are based upon

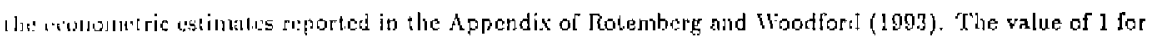


EKI (which would follow Irom a Cobb-Douglas production function for value added) is atandard in the real business cycle literalure and in a great many other computational general equilibrium atudies.

We next consider the parameters of household preferences. As noted above, the rate of lime preference is implicitly determined by our specification of $r$. It is useful to discuss the utility funetion $U(A, H)$ in terms of the Frisch demand functions $A^{d}\left(w^{A}, \lambda\right), H^{A}\left(w^{A}, \lambda\right)$ that it implies, where $w^{A}$ denotes the "comeumption wagen defined in section 2, and $\lambda$ denotes the repregentative household's marginal utility of wealth (with wealth in units of the composite good A). ${ }^{22}$ In order for a steady-gtate balanced growth path to be possible, it is necessary to make a homogeneity asoumption on the Frigch demands. ${ }^{29}$ Specifically, we assume that Wiere exists a $\sigma>0$ such that $H^{\prime}\left(w^{A}, \lambda\right)$ is homogeneous or degree zero in $\left(w^{A}, \lambda^{-1 / \sigma}\right)$, while $A^{d}\left(w^{A}, \lambda\right)$ is homogeneous of degrec one in ( $w^{4}, \lambda^{-1 / \sigma}$ ). (This is the homogeneity assumption referred to in seetions 1 and 2, thal is important for the result that a tax on direct household use of energy has no efect on non-energy output.) In our numerical work we furthermore specily the value of 2 for $\sigma$. As is noted in Table 1 , this value implies that the elasticity of consumption growth (apecifically, growth in consumption of the aggregate 4) between two periods, with respect to the real rale of return between those periods (also measured in lerms of the compasile good $A$ ), holding hours worked constant, is equal to 5 . This value (which follows Rolemberg and Woodford (1993)) is within the range of values consigient with a variety of atudies of the relation between intertemporal substitution in consumption and asset prices. (A value of 1 is common in the real busincss cycle literature.)

The only features of the Frisch demands that mat ter for the log-linear approximation to the equilibrium conditions are the elasticities of the functions with respect to theit two arguments, again evaluated at the steady-state equilibrium. IIowever, the homogeneity assumption atated above implies that all four elasticities are uniquely determined once we specify values for $\sigma$ and any one of the elasticities. Whe choose to calibrate lic model in terms of a specified value for $\epsilon_{H} w$, the elasticity of the Frisch labor supply funclion with respect to the consumption wage, because this particular elasticity (sometimes called the "intertemporal elasticily of labor slipply") is bolh familiar and the subject of a large number of econometric studies. Tlie value that we

\footnotetext{
22 For remonstration of how the equilibrium condiciona can convenitatly be written in terma of the Friach demand functions, ime Palemlyerg and Woodford (19G3). The discussion below of lhe pastmeterization of the Frisch demand functiana followa Rolethibreg and Woodford (1992).

2J'Tlis is equivatent to homogencity assumption on the function $U$. For further discussion of the clast of functiona $U$

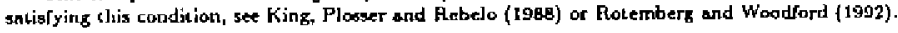


assume (again following Rotemberg and Woodtord (1993)) is at the high end of the range or values obtained [roun pastel data studies, though it is considerably smaller than the values most often assumed in the real business cycle literature (oflen 4 ar more).

'The remaining feature of household preferences to specily is the aggregator function $A\left(C, E^{k}\right)$. Again, because we assume that the tunction is homogeneous degree one, the only parameters for which numerical valucs are needed are the elasticities of $A$ with respect to its two arguments, and the elasticity of subatitution between the two arguments, again evaluated at the steady-state equilibrium consumption bundle. The elasticities with respect to the arguments are again implied by the share parameters specified above. For nxample, the elasticity of $A$ with respect to $C$ is given by

$$
\frac{C}{C+p_{E} E^{h}}=\frac{s_{C}\left(1-s_{M}\right)}{s_{C}\left(1-s_{M f}\right)+\frac{s^{h}}{1-q^{h}} s_{E}}
$$

Thus it rertains only to specify $\epsilon_{C E}$. Our value is taken ftom the econometric study by Houthakker, Verieget and Sheehan (1974)

We finally describe the parameters that specily the product markel siructure. As noted in the text, all of the models that we consider amount to different specifications of the markup function $\mu(X / Y)$ in equation 6. The features of this funciion tlat matler for the log-linear approximation to the equilibrium conditions are its value $\mu$ in the steady-state equilibrium, and the elasticity of the function with respect lo iLs argument $K / Y$, also evaluated at the stead $y$-state vaiue of that argument. In the case of the comperitive model, we apecily $\mu=1$ and $c_{\mu}=0$, In the case of the monopolisticaly competitive (or "constant markup") model we speci[y $\mu=1.2$ and $\epsilon_{\mu}=0$. In the case of the oligopolistic (or "vatiable markup") model, we specily $\mu=1.2$ and $\epsilon_{\mu}=.15$. As we discuss further in Rolemberg and Woodlord (1992), the amount of market power assuned in the steady state in the ease of the impertectly eompetitive specifications (prices $20 \%$ in -xcess of norginal cost) is within the cange of estimates obtained by a number of studies or U.S. industrjes. II Lliat sane paper we show that the implicjt collusion model implies theoretical bounds upon the value of $\epsilon_{\mu}$, manely, that $0<\epsilon_{\mu}<\mu-1$. The value that we assume here satisfies the theoretical bound. These parameter values for the inplicit collusion spodel also coincide wilh those that are shown in Roternberg and Moodford (1993) to pratict cfiects of oil price slocks that are similar to hiose observed during the period $19 \cdot 1 \bar{i}-1$ บ80.

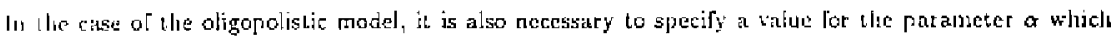


appears in the definition of $X$ proyided in Rolemberg and Woodford (1992). This parameler indicates the expectert vale of grow th of a given oligopoly's share in total expenditure. We assume $\alpha=9$, because, as is Jiscussed in the Appendix of Rotemberg and Woodford (1992), this value is consistent with the existence of an equilibrium wilh imperfect collusion (a binding incentive compatibility constraint) in the case of oligopolies with no more than ten firms.

Finally, in the case of either of the imperfectly competitive models, we must specify the parameter $\rho$ in equation 13. We set this arbilrarily at .2. This parameter does not seern to have an important qualitative effect on our results as long as it is relatively amall (adjustment of number of firms is not too last). 
Table 1

Energy Use in the U.S. Economy

Quantity Price Value

Conl

Production

Exports

For Electricity

Other uses

short tons

100 short tons

800 short tons

100 short tong

$30 /$ ton

3

Petroleum

Production

2707

Million Barrel

16.54 /barrel

44.77

Imports

2223 Million Barrel

16.54 /barrel

36.77

For electricity

196 Million Earrels 18.65 /barrel 3.70

Petroleum and Coal processing

Value added

Natural Gas

Tolal Revenues

For Elertricity

Other uses

Electric Utilities

Total revenues

36.70

Total Purchases

$\begin{array}{lll}2.79 \text { Trillion Cu.Ft. } 2200 \quad / \text { Cu.Ft. } & 69.07 \\ 6.10 \\ 62.93\end{array}$

184.90

355.41 
Table 2

The Calibrated Parameters

\begin{tabular}{|c|c|c|}
\hline Parameter & Values & Description \\
\hline$g$ & .03 & Rale of lechnical progress (per year) \\
\hline$r$ & .06 & Steady state real rate of return (per year) \\
\hline s & .073 & Rate of depreciation of capital stock (per year) \\
\hline$s_{C}$ & .697 & Share of private consumption in final usea \\
\hline$s_{r}$ & .186 & Share of private investment in final uses \\
\hline$n g$ & .117 & Slare of government putchages in finai uses \\
\hline$s_{E}$ & .02 & Share of energy coets in total costs \\
\hline$s_{M}$ & .5 & Share of materialg costs in total costs \\
\hline$s_{H}$ & .36 & Share of labot costs in total costs \\
\hline$s_{K}$ & .12 & Share of capital costs in total costs \\
\hline$s_{\oplus}$ & $0, .167$ & Share of fixed costs in total costs \\
\hline$\theta^{\text {dam }}$ & 83 & Share of domestically produced energy in total energy use \\
\hline$\theta^{h}$ & .4 & Share of direct household use in total energy use \\
\hline$y^{y}$ & .17 & Slsare of hours hired by the government. \\
\hline$\iota_{V G}$ & .69 & Elasticity of substitution between value added and intermediate inputs \\
\hline CEMt & .18 & Elasticity of substitution between energy and malerials \\
\hline$e x i$ & : & Elasticity of substitution between capital and lours \\
\hline $1 / \sigma$ & .5 & Elasticity of interternporal substitution of houseitold expenditure \\
\hline$c / i w$ & 1.3 & Intertemporal elasticity of labor supply \\
\hline$\mu$ & $1,1.2$ & Steady state markup (ratio of price to marginal cost) \\
\hline$\epsilon_{n}$ & $0, .15$ & Elasticity of the markup with respect to $X / Y$ \\
\hline or & 9 & Expected rate of growth of individual oligopoly's expendilure share \\
\hline$p$ & .2 & Rate of partial adjustment of number of firms \\
\hline
\end{tabular}


Table 3

Long-Run Eflects of an Energy Thx

\begin{tabular}{|c|c|c|c|c|}
\hline & \multicolumn{2}{|c|}{ [TAX ON ALL ENERGY USE] } & [HOUSEHOLD USE & \multirow{2}{*}{$\begin{array}{l}\text { ONLY] } \\
\text { et Power }\end{array}$} \\
\hline & Competitive & Market Power & Competitive & \\
\hline Non-Energy Output & -.071 & -.097 & 0 & 0 \\
\hline GDi & -.072 & -.098 &,- 022 & -.022 \\
\hline Hours Worked & +.024 & -.021 & 0 & 0 \\
\hline Product Wage & -.058 & -.085 & 0 & 0 \\
\hline Consumplion Wage & -.092 & -.122 & -.037 & -.037 \\
\hline Energy Use in Prod. & -.271 & -.297 & 0 & $a$ \\
\hline Jlousehold Energy & -1.052 & $-1,082$ & -1.000 & -1.000 \\
\hline Capitial Stock & -.084 & -.110 & 0 & 0 \\
\hline Number of Firms & - & -.033 & - & 0 \\
\hline
\end{tabular}


Figure 1

Estimoted Production Functions

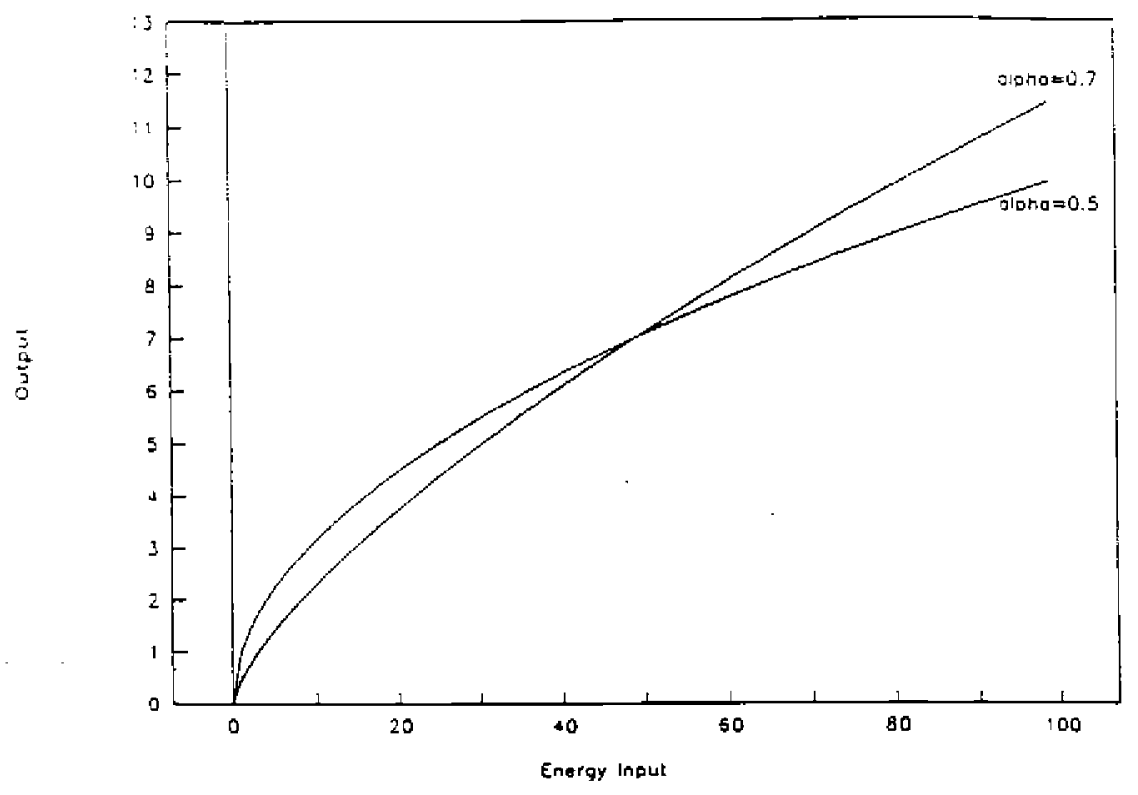


Figure 2

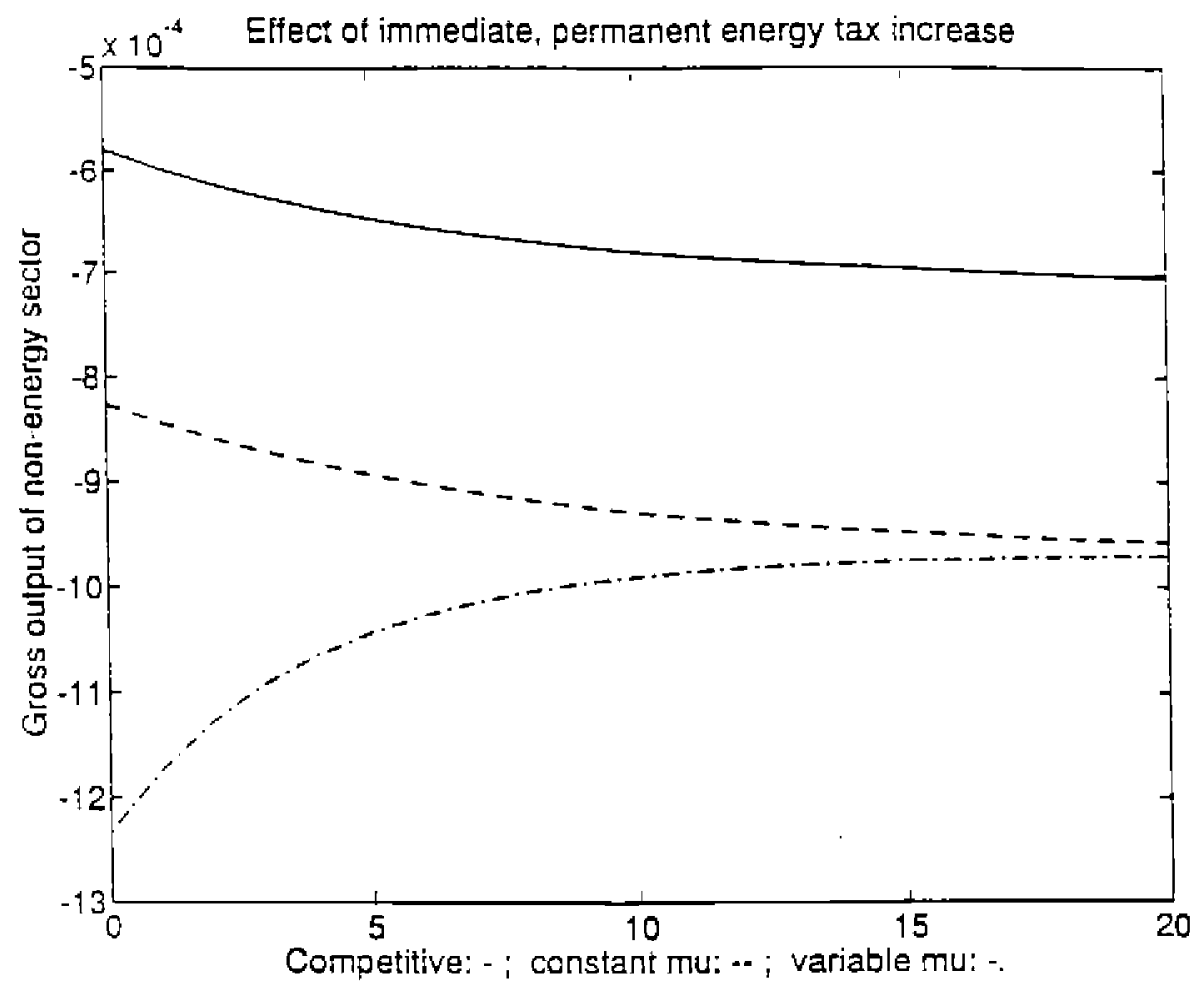


Figure 3

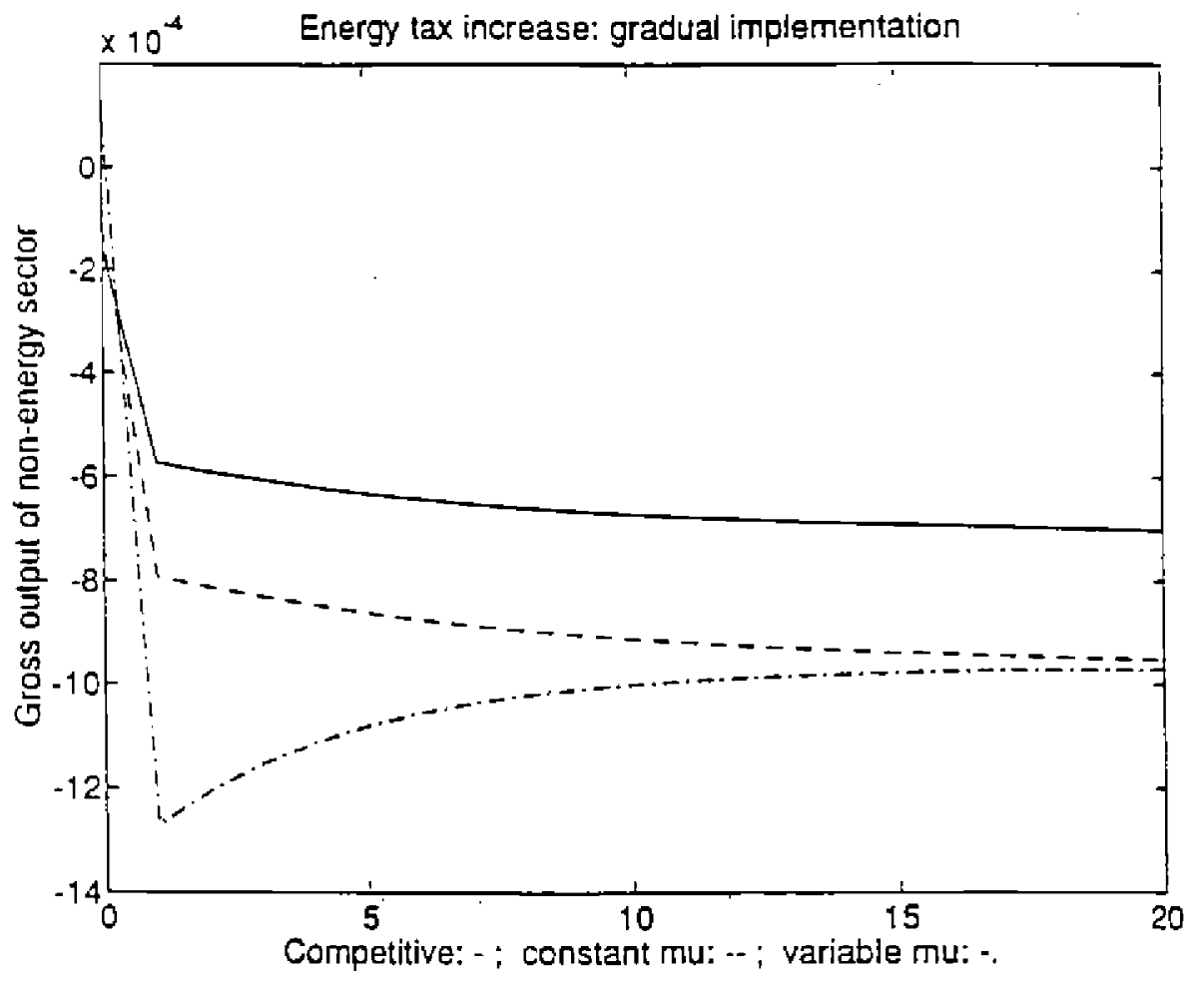




\section{Figure 4}

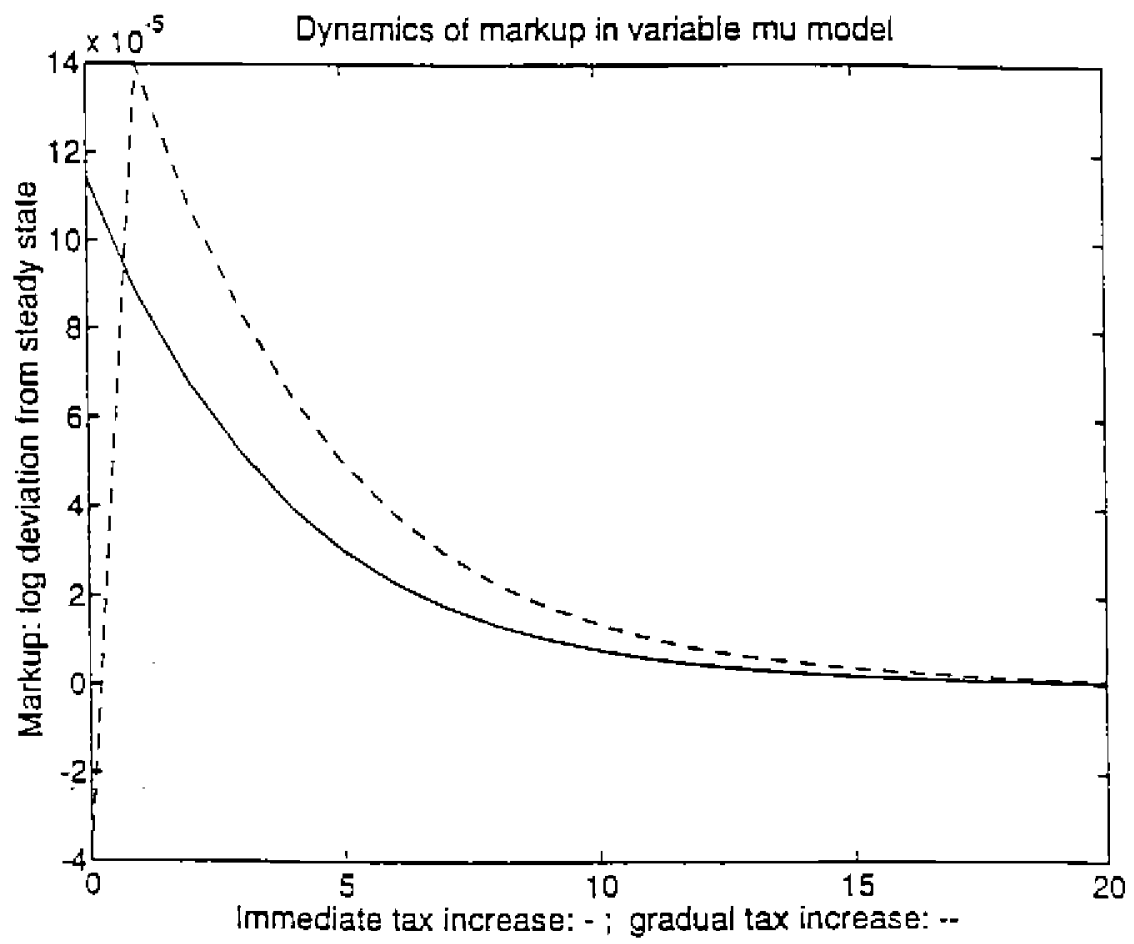




\section{Figure 5}

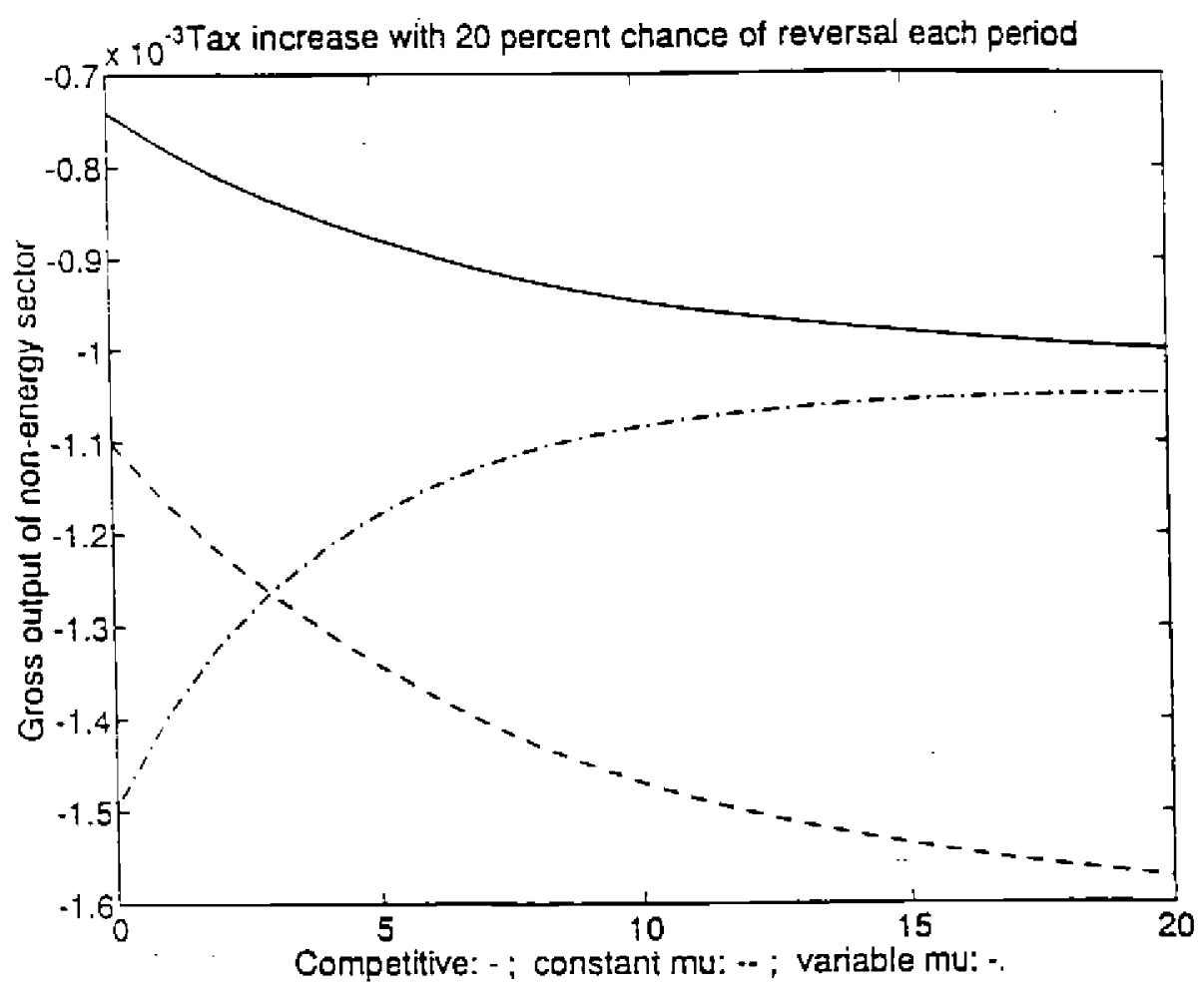

